\title{
Electrical Power Distribution Network Reliability: A Case Study in Wates Substation, Yogyakarta, Indonesia
}

\author{
Girindra Rosyadi ${ }^{1}$, Ramadoni Syahputra ${ }^{* 1}$, and Faaris Mujaahid ${ }^{1}$ \\ ${ }^{1}$ Department of Electrical Engineering, Universitas Muhammadiyah Yogyakarta \\ Jl. Lingkar Selatan, Tamantirto, Kasihan, Yogyakarta, Indonesia \\ *Corresponding author, e-mail: ramadoni@umy.ac.id
}

\begin{abstract}
This paper presents electrical power distribution network reliability. Reliability is one of the most critical factors of a network operating system that is supported. Several things become essential parameters in determining an index that complements the distribution system, namely SAIFI and SAIDI. This research is able to know about the high levels obtained by the distribution system at the Wates substation. With this analysis, it is expected that this will become a reference for improving service quality in the coming year. Based on the results of calculations and analyses that have been done, it can be said that the distribution system at the substation has been reliable, because all feeders have met the standards set by the SPLN, IEEE, and WCS, especially the WT 05 feeder meets the standard.
\end{abstract}

Keywords: Reliability, distribution network, SAIDI, SAIFI

\section{Introduction}

In this era, we cannot escape from the daily electricity needs. Almost all of our daily activities are related to electricity [1]. We use electricity to support our various daily activities that use a variety of electronic goods. Of course, this is very helpful for humans to do their daily activities [2]-[5]. Various types of activities ranging from the use of electricity in the household sector, public facilities, the industrial sector, even the government sector, require electricity. Therefore, from year to year electricity demand is increasing. The electricity needs must be balanced with an increase in power generation and the ability of its infrastructure. So that electricity distribution to consumers can run with standards that have been set [6]-[9].

To meet the needs of electricity itself requires a distribution system that has a high level of reliability [10]. High reliability means that in the distribution system, there are rarely disturbances or errors in the system in its operation. Because of the significant role in the use of electricity in their daily lives, the continuity of electricity supply is also a significant demand by consumers [11]-[15].
Therefore the existence of a reliable electric power system is prioritized in its application. To be able to know the reliability in the distribution of electricity to consumers, it is necessary to calculate the reliability index. By using failure data in the substation transformer, we can calculate the substation transformer reliability index. The level of service reliability depends on how long the blackout occurred during a specific time interval (one year) or SAIDI and how often the blackout occurred during the year or SAIFI [16]-[19].

The objectives of this research are as follows:

1. Calculate and analyze the level of reliability of SAIFI, SAIDI, and CAIDI feeders at PT. PLN Yogyakarta in 2014-2017 and compared with the performance targets set by PT. PLN Yogyakarta.

2. Calculate and analyze the level of reliability of SAIFI, SAIDI, and CAIDI feeders at PT. PLN Yogyakarta in 2018 and compared with standard SPLN, IEE, and WCS index values using the Matlab Graph.

3. Calculate and analyze the level of reliability of SAIFI, SAIDI, and CAIDI in PT. PLN Yogyakarta in 2018 and compared with international standards IEEE std 1366-2003 and WCS.

4. Calculate and analyze the peak load that 
occurred at Wates substation Yogyakarta in 2018.

\section{Literature Study}

\section{II.1 Electrical Power System}

The system is all the elements that are regularly interconnected and work together to be able to produce something [20]. So what is meant by the Electric Power System are several pieces of equipment or equipment consisting of generation, distribution, distribution, and customers, which are related to one another and work together to produce electricity. Individuals and industries consume electricity [21]-[23].

This means that electricity is essential for the continuity of the production process, both small, medium, and large industries. The power delivered for the generator must be processed first. In the distribution of electricity from power plants to consumers, there are many stages. The transmission of electric power in enormous quantities over very long distances is most efficient using high voltage [24]-[26]. High voltage is used on the transmission line to reduce power losses in the transmission line. The electrical power system scheme can be seen in Figure 1.

Reliability can be interpreted as optimizing the performance of a system in a predetermined period in all excellent or adverse conditions [27]. The level of quality in an electric power distribution system depends on the reliability of an electrical energy distribution system itself. If the distribution of electrical energy is far from reliable, then automatically, the supply of electrical energy will not run following consumer expectations. Due to the poor service quality and reliability, it is very closely related to the high level of a system outage [28]-[29].

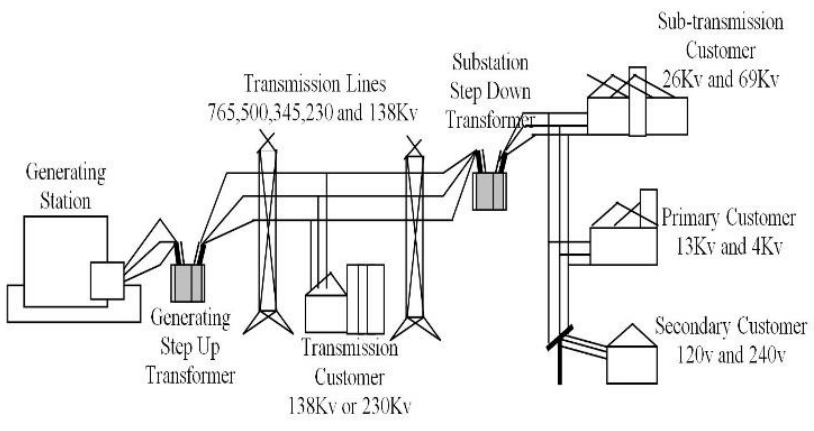

Fig. 1. Electrical power system scheme

With the concept of reliability in the system, it is highly expected that it can be a parameter of continuity of supply of electrical energy to consumers because, in the absence of reliability of electric power distribution, it will be challenging to examine deficiencies in a distribution system.

In general, Power Plants have a considerable distance from the center of the load so that in order to channel electricity from the plant to the consumer, there must be a channel that supplies electrical energy from the load center to the consumer. In the distribution network system there are 2 kinds of network systems, namely primary and secondary, both are differentiated based on the voltage, generally in the primary network the voltage is $20 \mathrm{kV}$ and the secondary distribution network is $380 \mathrm{~V}$ or $220 \mathrm{~V}$, the selection criteria is based on several factors, including:
a. Economic Factors
b. Eligibility Factor
c. Place Factor

The selection of network systems must meet the criteria of requirements, namely:
a. High-reliability
b. High continuity
c. Low frequency and voltage fluctuations
d. Low investment cost

\section{II.2 Distribution Network System}

The primary distribution network is a network that is located before the distribution substation functions to be able to deliver medium voltage electricity (for example, $6 \mathrm{kV}$ or $20 \mathrm{kV}$ ). The line can be in the form of cables in the ground or air ducts/wires connecting the substation (secondary transformer) to the distribution substation or relay substation (the transformer primary side is distributed). The secondary distribution network is a network that is located after the distribution substation and functions to supply low-traded electricity (for example, $220 \mathrm{~V} / 380 \mathrm{~V}$ ). Conductors in the form of ground wires or aerial wires connecting from the distribution substation (secondary side of the distribution transformer) to the consumer's premises (for example, industry or homes). Whereas for the distribution substation itself is a place/facility, where there is a step-down transformer that is a transformer that decreases the voltage from the medium voltage to a low voltage (according to consumer needs). Based on the network configuration, the distribution network system can be grouped into 3 (three) types, namely radial, loop, and spindle distribution network systems.

The secondary distribution system, commonly called the low voltage network, starts from the 
secondary side of the distribution transformer up to the customer's house connection which functions to distribute electrical energy from the distribution substation to the customer with an operating voltage that is low voltage (400/230 Volts, 380/220 Volts). The distribution system is divided into two, namely:

1. Low Voltage Air Ducts

The type of conductor used is insulated wire such as LVTC (Low voltage Twisted Cable)

2. Low Voltage Cable Channels

Judging from the actual function of the same as the Low Voltage Air Line, only the Low Voltage Cable Line is planted in the ground.

At this time Low Voltage Air Channels that use cables have been widely used by PT PLN to reduce the interference caused by external disturbances such as trees and interference caused by humans. For home connection to customer cables, twisted cables with aluminum core and copper are used.

An excellent secondary network at this time must be able to provide a level of reliability in low voltage networks in areas with high load densities and can guarantee electrical energy that will reach consumers has a good quality so that high costs can be accounted for and this level of reliability in consider it necessary.

Low voltage secondary network gets the most charging from three or more feeders, so if one of the feeder feeders is disturbed, the rest of the secondary network will be able to accommodate the load of the interrupted feeder comfortably. Such a system is called a second contingency network. Low voltage secondary network must be designed in such a way as to be able to share the burden and regulation of voltage is excellent by the distribution network itself.

\section{Methodology}

In this study, the tools used are as follows:

1. Hardware

The hardware used by the author is 1 unit of Asus A456QR laptop, 1 unit of the printer and $16 \mathrm{~GB}$ flash storage

2. Software

The software used is Microsoft Word 2016, Microsoft Exel 2016, and Matlab software.

3. Material for data collection in PT. PLN (Persero) Yogyakarta, journals, conferences, and research supporting books.

The place for the research was at PT. PLN Yogyakarta, which is located on Jl. Gedongkuning No. 3, Banguntapan, Bantul, Yogyakarta City,
Special Region of Yogyakarta, Substation Wates address at Jl. Glagah Beach, Kendeng, Plumbon, Kulon Progo, Special Region of Yogyakarta, Indonesia.

The following is an explanation of the course of the research conducted.

1. Field observation methods

The first step is to consult PT PLN Yogyakarta to collect data or everything related to the distribution system and make direct observations of the field conditions.

\section{Problem Identification and Formulation}

After conducting the first stage in-depth, then the next step is to identify the problems found in the research location. After finding the problem and the cause of the problem, in tracing the problem, the data is collected about the power distribution system. In this case, the problem that became the main topic was the Reliability Analysis of the Electric Power Distribution System at PT PLN Yogyakarta.

3. Literature Study

A literature study is done by reading books and searching for various kinds of literature via the internet about journals or research of others. A literature study was conducted to look for theoretical explanations about SAIFI, SAIDI, CAIDI as an index of the reliability of the distribution system.

\section{Data Collection}

Retrieval of data is done directly at PT PLN Yogyakarta, Wates substation, and ULP Wates aim to obtain valid data regarding the reliability of each feeder there.

The following data is needed as documentation:

a. A number of customers supplied by PT PLN Yogyakarta

b. Data feeder PT. PLN Yogyakarta:
1. Feeder Length
2. Feeder loading power
3. Number of feeder distribution transformers
c. Interference data such as:
1. Feeders who are having problems
2. Time out
3. Enter / restart

\section{Results and Discussion}

\section{IV.1 Feeders in Wates Substation}

After the research is done in the Wates substation, data on the feeder is used to meet the electrical energy needs in the Wates area. Based on the results 
of research in mind that the Wates substation has seven feeders to distribute electrical energy. The following is a list of feeders on the Wates substation.

Interference data at Wates substation includes some data, namely:

1. Exit Time (Off)

2. Enter Time (On)

3. Length of Outage (Duration)

From some of the aspects above, we will be able to find out when the electricity was recorded to go out when the electricity was back on, and how long the duration of the blackout occurred. In the calculation of the duration of the outage, we will be able to find out the duration of the disturbance in minutes. While the failure rate is only shown in the total number of times, a feeder goes on a trip for one year. The following data is a disturbance that occurred at Wates substation during 2018 each month.

After knowing the data about the frequency of interference, the next is how to create graph output using the Matlab application. For Matlab graphs, two outputs are used: bar graph output and plot graph. Here is how to make a graph.

a. Open the Matlab application

The first step is to make sure we have installed the Matlab application, for Matlab that we use is Matlab in 2009, the first step is to open the Matlab application by double-clicking on the existing Matlab icon.

b. Enter the value input for the bar graph

Once opened, two screens will appear, namely the Matlab screen and the command window (Figure 2 and Figure 3), then in the command window field enter the input data ie,

$$
\begin{aligned}
& \mathrm{x}=[1,2,3,4,5,6,7] ;=\text { for input } \mathrm{x} \text { value } \\
& \mathrm{y}=[0,0,0,0,3,1,0] ;=\text { to input the value of } \mathrm{y} \\
& \text { bar }(\mathrm{x}, \mathrm{y}) ;=\text { to display the bar graph }
\end{aligned}
$$

The $\mathrm{x}$-axis is the feeder in the Wates substation, for the $y$-axis is the input value entered by each feeder following the data obtained. When finished, press enter. Then the graphic image will come out.

c. Enter the value input for the plot graph

Then do the same in the command window column by entering

$$
\mathrm{x}=[1,2,3,4,5,6,7] ;=\text { for input } \mathrm{x} \text { value }
$$$$
y=[0,0,0,0,3,1,0] ;=\text { to input the value of } y
$$

plot (x, y, '- gsquare', 'linewidth', 2); = to display the plot graph

To display the actual plot graph, enter the input plot (x, y); but we can add input ('-') for dashed lines ('gsquare') for green lines and squares at each point. After finishing the press enter.

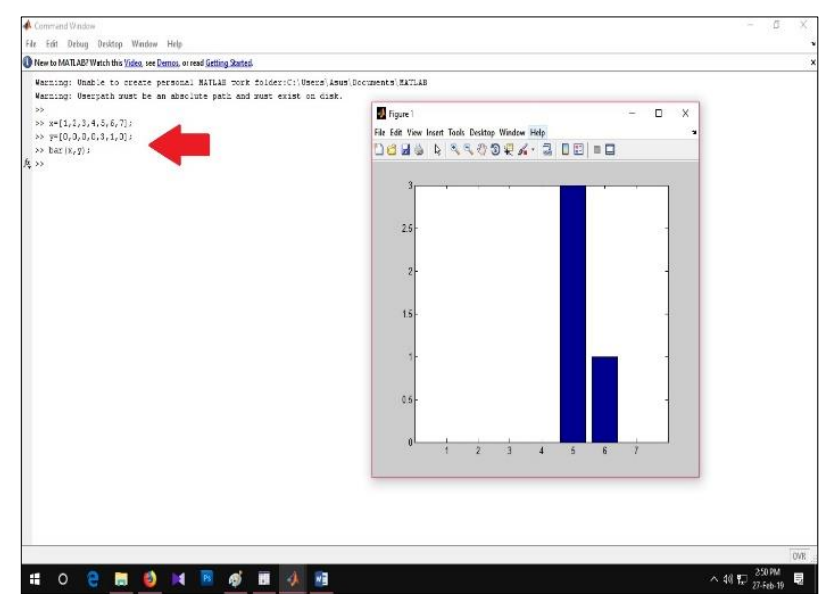

Fig. 2. Input data in Matlab command window for bar type

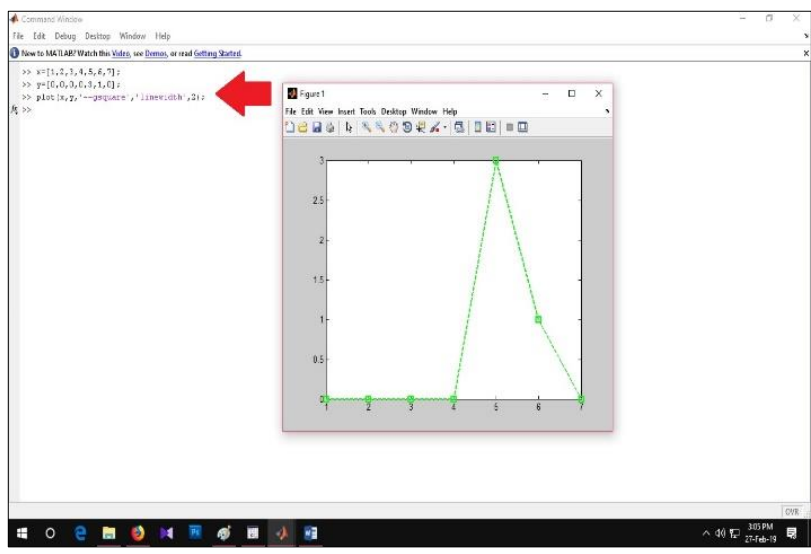

Fig. 3. Input data in Matlab command window for plot type

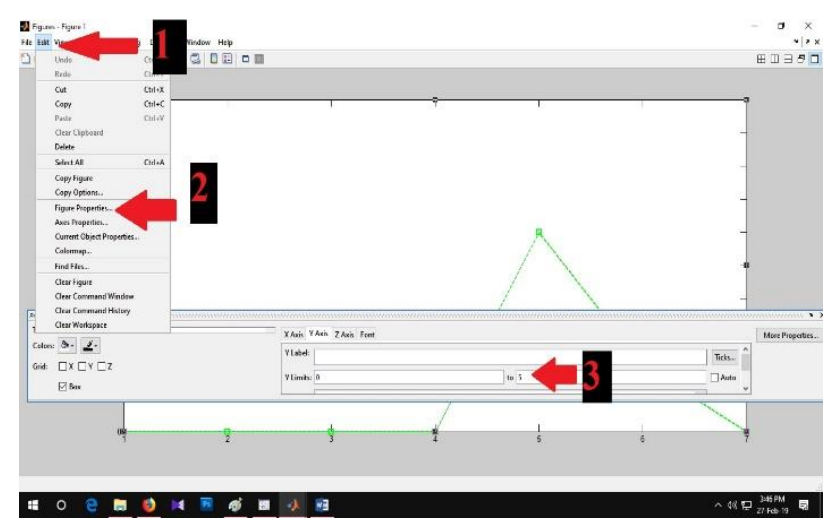

Fig. 4. Giving constraints on the y-axis

After the entire steps were done, then we can then give some variations to give the maximum limit on the Y-axis by pressing the edit button. Next, select the figure properties, the editor property will appear. In the editor, the settings are made on the y-axis column, which is changed to 5 , as seen in Figure 4. 


\section{IV.2 SAIFI Analysis in Wates Substation}

For the calculation of the SAIFI value, several factors that determine the outcome are the frequency of interruptions or the number of failures, the number of customers per feeder, and the total number of total customers.

From the graph in Figure 5, it can be seen that the WT 05 feeder is a feeder that receives the highest SAIFI value among other feeders. This value can occur because the WT 05 feeder has the highest frequency of disturbance compared to other feeders, which is seven times in 2018.

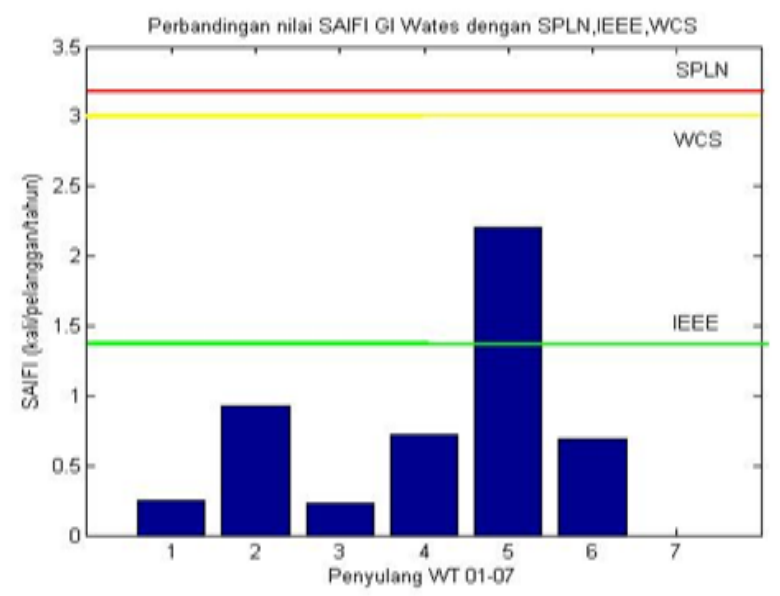

Fig. 5. Results of SAIFI in Wates substation

From the graph in Figure 5, it can be seen whether the distribution system from GI Wates can be said to be reliable or not, then we refer to the SAIFI calculation results that have been done. If the results are obtained, the next step is to compare the results with the provisions that have been determined, for example, from SPLN, IEEE, and WCS.

From the graph in Figure 5, we can find out whether or not SAIDI is reliable in the Wates substation, so the SPLN, IEEE, and WCS standards are used as a reference. After comparing SAIDI values on Wates substation with SPLN, IEEE, and WCS, all of them have met the standards and can be categorized as reliable in distribution.

However, in WT05 feeders, when compared with the standard of WCS, the feeder still cannot be said to be reliable, because the WCS standard is 1,666 hours/customer/year, while the SAIDI value in the WT05 feeder is 2.00 hours/customer/year, therefore it still cannot be said to be reliable. However, the difference in values obtained with these standards is not far, with the improvement of Maintenance and Management of the appropriate Substation Component as well as increasing the performance of the workers, the problem will be overcome for years to come.

\section{Conclusion}

This study discusses the reliability study of Wates substation. Reliability analysis is fundamental to evaluate and monitor a substation. The substation is the center of the electricity distribution network. Based on the calculation results and Comparison with Standards that have been set by PLN, IEEE, and WCS, it can be seen that for the SAIFI values obtained at the Wates substation can already be said to be reliable as a whole, there is only 1 Feeder namely WT 05 that does not meet the standards IEEE with a value of 2.21 times/customer/year while the IEEE standard is 1.45 times/customer/year.

\section{References}

[1] Brusco, G., A. Burgio, D. Menniti, A. Pinnarelli, N. Sorrentino. (2014). Optimal Sizing of DGs for a CHP-Based Agro-Industrial Microgrid with a Priority Criteria Operational Strategy, International Review of Electrical Engineering (IREE), 9(2), pp. 351-362.

[2] Syahputra, R., Soesanti, I. (2017). Modeling of Wind Power Plant with Doubly-Fed Induction Generator. Jurnal Teknologi, Journal of Electrical Technology UMY (JET-UMY), 1(3), pp. 126-134.

[3] Syahputra, R., Soesanti, I. (2016). DFIG Control Scheme of Wind Power Using ANFIS Method in Electrical Power Grid System. International Journal of Applied Engineering Research (IJAER), 11(7), pp. 5256-5262.

[4] Syahputra, R., Wiyagi, R.O., Sudarisman. (2017). Performance Analysis of a Wind Turbine with Permanent Magnet Synchronous Generator. Journal of Theoretical and Applied Information Technology (JATIT), 95(9), pp. 1950-1957.

[5] Syahputra, R., Soesanti, I., Ashari, M. (2016). Performance Enhancement of Distribution Network with DG Integration Using Modified PSO Algorithm. Journal of Electrical Systems (JES), 12(1), pp. 1-19.

[6] Syahputra, R., Robandi, I., Ashari, M. (2015). Performance Improvement of Radial Distribution Network with Distributed Generation Integration Using Extended Particle Swarm Optimization Algorithm. International Review of Electrical Engineering (IREE), 10(2). pp. 293-304.

[7] Syahputra, R. (2017). Distribution Network Optimization Based on Genetic Algorithm. Jurnal Teknologi, Journal of Electrical Technology UMY (JET-UMY), 1(1), pp. 1-9. 
[8] Mujaahid, F., Fauzi, A.M., Syahputra, R., Putra, K.T., Purwanto, K. (2017). Potentials of Organic Waste Conversion in a Green Campus Concept. Journal of Electrical Technology UMY (JET-UMY), 1(4), pp. 183-188.

[9] Ahmed, J., Salam, Z. (2018). An Enhanced Adaptive P\&O MPPT for Fast and Efficient Tracking Under Varying Environmental Conditions, IEEE Transactions on Sustainable Energy, 9(3), pp. 1487 1496.

[10] Hui, J.C.y., Bakhshai, A., Jain, P.K. (2016). An Energy Management Scheme With Power Limit Capability and an Adaptive Maximum Power Point Tracking for Small Standalone PMSG Wind Energy Systems, IEEE Transactions on Power Electronics, 31(7), pp. 4861 - 4875.

[11] Hui, J.C.y., Bakhshai, A., Jain, P.K. (2015). A Sensorless Adaptive Maximum Power Point Extraction Method With Voltage Feedback Control for Small Wind Turbines in Off-Grid Applications, IEEE Journal of Emerging and Selected Topics in Power Electronics, 3(3), pp. 817 - 828.

[12] Syahputra, R., Robandi, I., Ashari, M., (2012), "Reconfiguration of Distribution Network with DG Using Fuzzy Multi-objective Method", International Conference on Innovation, Management and Technology Research (ICIMTR), May 21-22, 2012, Melacca, Malaysia.

[13] Syahputra, R., Robandi, I., Ashari, M. (2014). Optimization of Distribution Network Configuration with Integration of Distributed Energy Resources Using Extended Fuzzy Multi-objective Method. International Review of Electrical Engineering (IREE), 9(3), pp. 629-639.

[14] Jiang, R., Han, Y., Zhang, S. (2017). Wide-range, high-precision and low-complexity MPPT circuit based on perturb and observe algorithm, Electronics Letters, 53(16), pp. 1141 - 1142.

[15] Peng, B.R., Che, K., Liu, Y.H. (2018). A Novel and Fast MPPT Method Suitable for Both Fast Changing and Partially Shaded Conditions, IEEE Transactions on Industrial Electronics, 65(4), pp. 3240 - 3251.

[16] Hossain, M.K., Ali, M.H. (2013). Overview on Maximum Power Point Tracking (MPPT) Techniques for Photovoltaic Power Systems. International Review of Electrical Engineering (IREE), 8(4). pp. 1363-1378.

[17] Tang, L., Xu, W., Mu, C. (2017). Analysis for stepsize optimisation on MPPT algorithm for photovoltaic systems, IET Power Electronics, 10(13), pp. 1647 - 1654.

[18] Ghasemi, M.A., Ramyar, A., Eini, H.I. (2018). MPPT Method for PV Systems Under Partially Shaded Conditions by Approximating I-V Curve, IEEE Transactions on Industrial Electronics, 65(5), pp. 3966 - 3975.

[19] Soesanti, I., Syahputra, R. (2016). Batik Production Process Optimization Using Particle Swarm Optimization Method. Journal of Theoretical and
Applied Information Technology (JATIT), 86(2), pp. 272-278.

[20] Syahputra, R., Robandi, I., Ashari, M. (2015). PSO Based Multi-objective Optimization for Reconfiguration of Radial Distribution Network. International Journal of Applied Engineering Research (IJAER), 10(6), pp. 14573-14586.

[21] Metry, M., Shadmand, M.B., Balog, R.S., Abu-Rub, H. (2017). MPPT of Photovoltaic Systems Using Sensorless Current-Based Model Predictive Control, IEEE Transactions on Industry Applications, 53(2), pp. 1157 - 1167.

[22] Kebede, M.H., Beyene, G.B. (2018). Feasibility Study of PV-Wind-Fuel Cell Hybrid Power System for Electrification of a Rural Village in Ethiopia. Journal of Electrical and Computer Engineering, 2018.

[23] Soedibyo, Ashari, M., Syahputra, R. (2014). "Power loss reduction strategy of distribution network with distributed generator integration", Proceeding of 2014 1st International Conference on Information Technology, Computer, and Electrical Engineering (ICITACEE) 2014, UNDIP Semarang, pp. 404 408.

[24] Jamal, A., Suripto, S., Syahputra, R. (2015). MultiBand Power System Stabilizer Model for Power Flow Optimization in Order to Improve Power System Stability. Journal of Theoretical and Applied Information Technology (JATIT), 80(1), pp. 116123.

[25] Syahputra, R., Soesanti, I. (2015). Power System Stabilizer model based on Fuzzy-PSO for improving power system stability. 2015 International Conference on Advanced Mechatronics, Intelligent Manufacture, and Industrial Automation (ICAMIMIA), Surabaya, 15-17 Oct. 2015 pp. 121 126.

[26] Syahputra, R., Soesanti, I. (2016). Application of Green Energy for Batik Production Process. Journal of Theoretical and Applied Information Technology (JATIT), 91(2), pp. 249-256.

[27] L. Tang, W. Xu, C. Mu, "Analysis for step-size optimisation on MPPT algorithm for photovoltaic systems", IET Power Electronics, Vol. 10, No. 13, pp. $1647-1654,2017$.

[28] Sher, H.A., Addoweesh, K.E., Al-Haddad, K. (2018). An Efficient and Cost-Effective Hybrid MPPT Method for a Photovoltaic Flyback Microinverter, IEEE Transactions on Sustainable Energy, 9(3), pp. 1137 - 1144.

[29] Syahputra, R., Soesanti, I. (2016). An Optimal Tuning of PSS Using AIS Algorithm for Damping Oscillation of Multi-machine Power System. Journal of Theoretical and Applied Information Technology (JATIT), 94(2), pp. 312-326. 


\section{Authors' information}

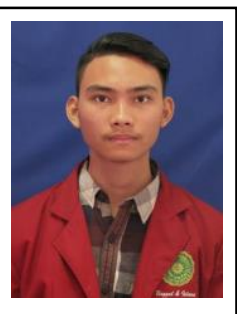

Girindra Rosyadi received B.Sc. degree from Department of Electrical Engineering, Universitas Muhammadiyah Muhammadiyah Yogyakarta, Yogyakarta, Indonesia.

His research interests are in operation of power distribution system and power distribution system planning.

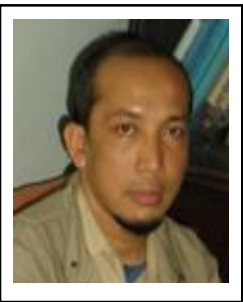

Ramadoni Syahputra received B.Sc. degree from Institut Teknologi Medan in 1998, M.Eng. degree from Department of Electrical Engineering, Universitas Gadjah Mada, Yogyakarta, Indonesia in 2002, and Ph.D. degree at the Department of Electrical Engineering, Faculty of Industrial Technology, Institut Indonesia in 2015.

Teknologi Sepuluh Nopember, Surabaya,

Dr. Ramadoni Syahputra is a Lecturer in Department of Electrical Engineering, Faculty of Engineering, Universitas Muhammadiyah Yogyakarta, Indonesia. His research interests are in computational of power system, artificial intelligence in power system, power system control, the application of fuzzy logic in power system, optimization, distributed energy resources, and renewable energy.

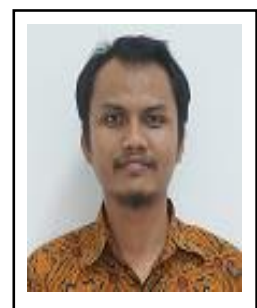

Faaris Mujaahid hold a bachelor degree in 2010 from Electrical and Electronics Engineering Department, Saxion University of Applied Sciences, the Netherlands. He received a master degree in Sustainable Energy Technologies in 2016 from University of Southampton, UK. ing. Faaris Mujaahid, M.Sc. is currently a lecturer in the Department of Electrical Engineering, Faculty of Engineering, Universitas Muhammadiyah Yogyakarta, Indonesia. His main research interest is in LabVIEW and renewable energy (mainly in solar cell material and fabrication technologies). 